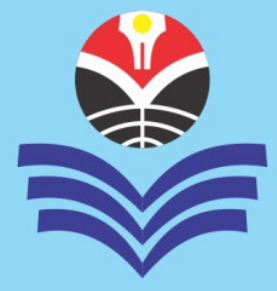

\title{
Emotional Intelligence and Leadership Trait among Master Teachers
}

\begin{abstract}
Many classroom teachers get promoted to a leadership role as in the case of Master Teachers in the Department of Education (DepEd) in the Philippines. This requires a shift in role or expansion of scope and nature of work as they adjust and accommodate the new assignment. Hence, this shift is worth studying to understand how they fare and what assistance can be given them to be effective in doing their tasks. This is the purpose of the current study focused on determining the emotional intelligence and leadership trait of the Master Teachers. Using a descriptive-correlational research method involving 45 respondents from the 10 Senior High Schools in Pasig City with Master Teachers, the study identified their emotional intelligence and leadership trait, and determined the significant correlations between the two as perceived by the participants. The results show that the respondents were highly emotionally intelligent in managing own emotions, managing others' emotions, and utilization of emotions, but they got above average emotional intelligence in the perception of emotions. On the other hand, the measure of leadership trait showed that they had high leadership trait in all the five major leadership traits.
\end{abstract}

KEY WORD: Emotional Intelligence; Leadership Trait; Master Teacher.

ABSTRAKSI: "Kecerdasan Emosional dan Sifat Kepemimpinan diantara Guru-guru Kepala Sekolah". Banyak guru kelas dipromosikan ke peran kepemimpinan seperti dalam kasus Guru-guru Kepala Sekolah di Departemen Pendidikan (DepEd) di Filipina. Ini membutuhkan pergeseran peran atau perluasan ruang lingkup dan sifat pekerjaan saat mereka menyesuaikan dan mengakomodasi tugas baru. Oleh karena itu, perubahan ini layak dipelajari untuk memahami bagaimana taraf mereka dan bantuan apa yang dapat diberikan kepada mereka agar efektif dalam melakukan tugas-tugas mereka. Ini adalah tujuan dari penelitian ini yang berfokus pada menentukan kecerdasan emosi dan sifat kepemimpinan dari Guru-guru Kepala Sekolah. Menggunakan metode penelitian deskriptif-korelasional yang melibatkan 45 responden dari 10 SMA (Sekolah Menengah Atas) di Kota Pasig dengan Guru-guru Kepala Sekolah, penelitian ini mengidentifikasi kecerdasan emosional dan sifat kepemimpinan mereka, dan menentukan korelasi yang signifikan antara keduanya seperti yang dirasakan oleh para peserta. Hasil kajian menunjukan bahwa responden sangat cerdas secara emosional dalam mengelola emosi sendiri, mengelola emosi orang lain, dan memanfaatkan emosi, tetapi mereka mendapat kecerdasan emosi di atas rata-rata dalam persepsi emosi. Di sisi lain, ukuran sifat kepemimpinan menunjukan bahwa mereka memiliki sifat kepemimpinan yang tinggi di semua lima sifat kepemimpinan utama.

KATA KUNCI: Kecerdasan Emosional; Sifat Kepemimpinan; Guru Kepala Sekolah.

About the Authors: Leilani C. Lucero, M.A. is a Head Teacher at the Pasig City Science High School in the Philippines; and Jose M. Ocampo, Jr., Ph.D. is a Lecturer at the PNU (Philippine Normal University) in Manila, the Philippines. For academic interests, the authors are able to be contacted via their e-mails at: leahcruzlucero@yahoo.com and juno_6970@yahoo.com

Suggested Citation: Lucero, Leilani C. \& Jose M. Ocampo, Jr. (2019). "Emotional Intelligence and Leadership Trait among Master Teachers" in MIMBAR PENDIDIKAN: Jurnal Indonesia untuk Kajian Pendidikan, Volume 4(1), Maret, pp.55-72. Bandung, Indonesia: UPI [Indonesia University of Education] Press, ISSN 2527-3868 (print) and 2503-457X (online).

Article Timeline: Accepted (January 15, 2019); Revised (February 9, 2019); and Published (March 30, 2019). 


\section{INTRODUCTION}

The EI (Emotional Intelligence) is a vital factor for having success in social institutions, because it shows how an individual applies knowledge to different circumstances in life. It is a group of social, personal, and emotional skills and abilities that affect how a person copes with different clamor and tensions (Bar-on, 1997; and Dollard, 2018). The overall emotional health is affected by EI in identifying a person's ability to have a successful life and influence their psychological well-being (Reissland, 2012; and Poonamallee et al., 2018). It is about handling relationships, reading non-verbal messages and cues, and how to manage those cues and being able to control emotions in times of struggles (Zoller \& Pieston, 2014; and Drigas \& Papoutsi, 2018).

EI works with IQ (Intelligence Quotient) and top performers possess both. The harder the job or the bigger the problem, the more important the role of EI is. It helps in picking up what emotional tricks people have over their sleeves to know, when to praise, persuade, laugh loudly at jokes, and show empathy (Singh, 2015; and Dollard, 2018).

People at the top of their respective fields are not only intelligent, but also resilient and optimistic. To be successful at what people are doing takes more than the cognitive skills but also being emotionally intelligent (Wilding, 2010; and Patti et al., 2018). It is referred to as the extent to which a person adequately deals with affective information (Cherniss, 2006; and Mayer, Caruso \& Salovey, 2016). Some have conceptualized this construct as a trait; and others have conceptualized it as ability (Daloos, 2015; and Lopes, 2016).

The overall emotional health is affected by EI in identifying a person's ability to have a successful life and influence their psychological well-being. This implies that people have different skills and abilities to perceive, understand, and manage emotions (Reissland, 2012; and Drigas \& Papoutsi, 2018). Having emotional intelligence is about being mindful of own and other people's emotions. It is using emotions and how it can be managed (Hasson, 2012; and Poonamallee et al., 2018).

Trait EI, or "trait emotional self-efficacy", which refers to emotional perceptions measured via self-or-observer-reports; and ability EI, or "cognitive-emotional ability", which refers to cognitive-emotional abilities that ought to be measured via maximum performance test ( $c f$ Petrides, 2017; and Sathitsemakul, 2017). In the academe, EI has been connected to various parts of what is happening in school, for example, learning, scholarly accomplishments, and behaviors dictated by the society among students and the implication of effective teaching (Murphy, 2006; and Dolev \& Leshem, 2017).

Leadership Trait. Leadership is the manner, where a single person creates a positive impact to other people in achieving their goal. It cannot exist without influence and it includes attention to common goals. Leaders possess ethical values, because it is their responsibility to attend to the need and concerns of the group. Leaders and followers must work hand in hand and not above or below each other (Mihelic, Lipicnik \& Tekavcic, 2010; and Northouse, 2015).

Experiences act as the lesson for everyone to learn from, including the leaders, and they will continue with it, even without the interference of the organization (McCauley \& McCall, 2014; and Gleeson, 2015). Other people in the organization may also be leaders, because everybody can influence each other or those whom they supervise (Kreitz, 2009; and Kumar, 2014). It is the potential as the likelihood that people can become what they visualize themselves, or something more than what they currently are (Silzer \& Church, 2009; 
and Dollard, 2018).

A leader possesses the following qualities: passion, guiding vision, and integrity (Bennis, 2009; and Dumitru, Motoi \& Budica, 2015). Traits that leaders demonstrate under specific situations are composite in nature, which also supports the notion that traits evolve ( $c f$ Boateng, 2014; and Liguo et al., 2014). The success of a leader does not necessarily depend on traits, but the working relationship between the leader and other group members, and changing situations (Roberts, 2012; and Dollard, 2018).

\section{Emotional Intelligence and Leadership}

Trait. Emotional intelligence and leadership skills are two prevalent skills linked to successful performance in the workplace and effective leadership (Brown, 2014; and Miller, 2015). Two key concepts in organizational leadership are who the leader is (trait emotional intelligence) and how the leader interacts with the organization (leadership style). A quantitative explanatory study was done to assess the relationship, if any, between trait emotional intelligence and leadership style. The key finding of the study is that trait emotional intelligence, or personality by inference, significantly explains transformational, transactional, and passive/avoidant leadership style in professional engineers (Narong, 2015; and Hertwig, 2016).

Focusing on correlation of emotional intelligence and leadership among student-leaders based in D.P. Goleman (1995)'s Four Competencies, it was found that the four emotional intelligence competencies are indeed connected to leadership ( $c f$ Goleman, 1995; and Cobankiat \& Leehok, 2010). Authority and enthusiastic insight have turned out to be an intriguing issue in administration and association (Anand \& Udaya, 2010; and Clark, Golder \& Golder, 2010).

There is a positive relationship between emotional intelligence and effective leadership, indicating how EI (Emotional Intelligence) has become widely known as a tool to identify employees with potential of becoming effective leaders and as a measure for developing leadership skills (Batool, 2013; and Poonamallee et al., 2018). It would be helpful in making insights about the factors possibly affecting the development of emotional intelligence (Ang, Carlos \& Umali, 2014; and Poonamallee et al., 2018).

People who promote emotional intelligence showed that it brought positive outcome in their respective careers, because they influenced each other as they stayed attuned and connected together (Ishmaill et al., 2012; and Kannaiah \& Shanthi, 2015).

Air Force Staff Sergeant Supervisors' measurable transformational leadership competencies, and perceived emotional intelligence competencies, were significantly impacted resulting from completion of an emotional intelligence training program (Lough, 2016; and Walters, 2018).

Future research should focus on examining emotional intelligence as part of a leader's profile (Kannaiah \& Shanthi, 2015; and Toniono, 2015). Another quantitative study was done to examine the strength of the relationship between emotional intelligence and authentic leadership in Naval Special Warfare leadership. Results indicated that there was no statistically significant relationship between overall emotional intelligence, or any particular dimension of emotional intelligence, with authentic leadership. Further analysis also indicated there was no statistically significant relationship between age and emotional intelligence, or between age and authentic leadership (Berardi, 2015; and Wouters, Brull \& Lopez-Zafra, 2018).

Conceptual Framework. EI (Emotional Intelligence), or EQ (Emotional Quotien), is a term first published by two researchers: P. Salovey \& J.D. Mayer (1990), giving its meaning as a type of social intelligence 
that affects the capability of a person to monitor and observe his/her feelings as well as others' feelings and emotions; to identify the differences among them; and to use it to lead own thoughts and action ( $c f$ Salovey \& Mayer, 1990; Golis, 2007; and Mayer, Salovey \& Caruso, 2008). EI is the capacity to perceive and express emotion, compare emotions in thought, conclude and reason with emotion, and check and inhibit own emotions and in others (Salovey \& Mayer, 1990; Mayer \& Salovey, 1997; Golis, 2007; and Mayer, Salovey \& Caruso, 2008).

The present study is based on the J.D. Mayer, D. Caruso \& P. Salovey (2016)'s Emotional Intelligence Theory and the Northouse Leadership Theory. These are the most applicable theory and are very close to the characteristics of the Filipino teachers. The J.D. Mayer, D. Caruso \& P. Salovey (2016)'s Emotional Intelligence Theory describes that EI is divided into four areas of abilities: Emotional Perception, Emotional Facilitation, Emotional Understanding, and Emotional Management. The theory also includes four other related areas, but with well-defined abilities, namely: (1) Seeing emotions as the ability to know how an individual and those around him/ her are feeling; (2) Facilitating thought as the capacity to create emotions, and be able to explain its reason; (3) Understanding emotions as the capacity to comprehend emotions, which are complicated in nature and emotions associated with it, how it changes from one phase to another; and (4) Managing emotions as the capacity which helps the person to manage his/her own emotions and in others ( $c f$ Mayer, Salovey \& Caruso, 2008; Ragasa, 2013; and Mayer, Caruso \& Salovey, 2016).

N.S. Schutte, J.M. Malouff \& M. Bhullar (2009) have adopted the following dimensions of EI based on several factor analytic studies: Perception of emotions; Managing one's emotions; Managing others' emotions; and Utilization of emotions
(Schutte, Malouff \& Bhullar, 2009).

Managing and regulating of emotion reflect the capability of a person to stay open to feelings, give an eye on and regulate how emotions reflectively promote growth in emotions and intellect (Mayer \& Salovey, 1997; and Mayer, Salovey \& Caruso, 2008).

To be able to have an effective leadership, a leader should possess set of traits and involves the leader and his/her traits. This approach suggests that people are born with unique traits different from other people, and that such traits make them great leaders. The importance of having leadership traits is how it influences the subordinates by giving attention on understanding their feelings, behaviors, and thoughts that can boost their morale and passion to accomplish their task effectively towards their given objectives. Moreover, if the leaders have these traits, they can also handle their own feelings and emotions, and show favorable reaction to their followers (Northouse, 2013; and Kolzow, 2014).

There is a positive significant relationship between EI (Emotional Intelligence) and LT (Leadership Trait) as suggested by the findings of the studies just reviewed. For instance, EI predicts leadership styles and shows significant relationship (Burbach, 2004; Leigh, 2012; McCanon \& Jeanine, 2015; and Hertwig, 2016). EI has a significant relationship with leadership, leadership style, and effective leadership (Anand \& Udaya, 2010; and Cobankiat \& Leehok, 2010); and it also has a positive effect on leadership performance as well as leadership potential (Canlas, 2014; and Kolzow, 2014).

Studies also proved its correlation to organizational commitment, multitasking ability, experience at work, and work performance (Chishti et al., 2011; Ishmaill et al., 2012; and Ang, Carlos \& Umali, 2014). With regard to leadership traits, intelligence is strong factor to a person's verbal, perceptual, and reasoning ability. 
Table 1:

Emotional Intelligence Level of Master Teachers on PE (Perception of Emotion)

\begin{tabular}{lcl}
\hline Indicators & Mean & Verbal Interpretations \\
\hline 1. I find it hard to understand the non-verbal messages of other people. & 3.02 & Above Average \\
2. I am aware of my emotions as I experience them. & 4.31 & High \\
3. I am aware of the non-verbal messages I send to others. & 3.87 & Above Average \\
4. By looking at their facial expressions, I recognize the emotions people & 3.98 & Above Average \\
are experiencing. & & \\
5. I know why my emotions change. & 4.16 & High \\
6. I easily recognize my emotions as I experience them. & 4.09 & High \\
7. I am aware of the non-verbal messages other people send. & 4.11 & High \\
8. I know what other people are feeling just by looking at them. & 3.69 & Above Average \\
9. I can tell how people are feeling by listening to the tone of their voice. & 4.11 & High \\
10. It is difficult for me to understand why people feel the way they do. & 3.11 & Above Average \\
\hline Overall Mean & $\mathbf{3 . 8 4}$ & Above Average \\
& & Emotional Intelligence \\
\hline
\end{tabular}

Self-confidence is about being sure of one's abilities and skills. Determination is having the urge and desire to get the work done while integrity is about having the attitude of being honest and trustworthy. Lastly, sociability, on the other hand, is being capable of seeking social relationship (Northouse, 2013; and Kolzow, 2014).

Research problems are: (1) What is the level of EI of the Master Teachers in terms of the following components: Perception of Emotions, Managing Own Emotions, Managing Others' Emotions, and Utilization of Emotions?; (2) What is the LT of the Master Teachers in terms of the following components: Intelligence, Self-Confidence, Determination, Integrity, and Sociability?; and (3) What is the relationship between the EI and LT of Master Teachers?

\section{METHODS}

Using a descriptive-correlational research method involving forty five (45) respondents from the ten (10) Senior High Schools in Pasig City, the Philippines, with Master Teachers, the study identified their emotional intelligence and leadership trait, and determined the significant correlations between the two as perceived by the participants. The SSEIT (Schutte Self-
Report Emotional Intelligence Test) and the LTQ (Leadership Trait Questionnaire) were administered to them (cf Austin et al., 2004; Alston, 2009; Schutte, Malouff \& Bhullar, 2009; Olila, 2012; and Rafols, 2015).

\section{RESULTS AND DISCUSSION}

The table 1 shows the responses of the Master Teachers, each treated according to its weighted means.

Table 1 depicts that the participants got the lowest mean score on the indicator on understanding non-verbal messages of other people. The reason is that many of them are not sensitive to body language and nonverbal cues of others. As Teachers, they are prone to different kinds of stress; and due to this reason, stress compromises their ability to communicate and be sensitive with nonverbal messages of others. As explained by K. Zoller \& K. Pieston (2014), and other scholars, that emotional intelligence is about handling relationships; reading non-verbal messages and cues, and how to manage those cues; and being able to control emotions in times of struggles (Zoller \& Pieston, 2014; Drigas \& Papoutsi, 2018; and Poonamallee et al., 2018).

The second indicator that got the lowest mean score is the ability to understand why 
Table 2:

Emotional Intelligence Level of Master Teachers on Managing Own Emotions

\begin{tabular}{lcc}
\hline Indicators & Mean & Verbal Interpretation \\
\hline 1. When I am faced with obstacles, I remember times I faced similar & 4.42 & High \\
obstacles and overcame them. & 4.16 & High \\
2. I expect that I will do well on most things I try. & $4.44 \quad$ High \\
3. I expect good things to happen. & $4.11 \quad$ High \\
4. When I experience a positive emotion, I know how to make it last. & 3.98 Above Average \\
5. I seek out activities that make me happy. & 3.93 Above Average \\
6. I have control over my emotions. & 4.27 & High \\
7. I motivate myself by imagining a good outcome to tasks I take on. & 2.49 Average \\
8. When I am faced with a challenge, I give up because I believe I will fail. & 4.27 & High \\
9. I use good moods to help myself keep trying in the face of obstacles. & $\mathbf{4 . 0 1}$ & High Emotional \\
\hline Overall Mean & Intelligence \\
\hline
\end{tabular}

people feel the way they do. As Master Teachers, one of their work related task is to maintain a good relationship with teachers, and other school personnel, students, and community that's why understanding the feelings of others is vital for them. The promotion to Master Teacher position sometimes lead to envious reactions among co-teachers over their promotion, because of this sometimes it's hard for them to understand why certain people feel the way they do towards them (Zeichner, 2008; and Sabado, 2014).

Having emotional intelligence is tantamount to being capable of understanding feelings and using this capability and energy in productive ways. It concerns actions in which people recognize, understand, and apply their power in an effective way (Gardenswartz, Cherbosque \& Rowe, 2008; and Poonamallee et al., 2018).

On a positive note, the participants got the highest mean score on being aware of their emotions as they experience them. This is because perception of emotions is dependent on past experiences and interpretations (Dollard, 2018; and Poonamallee et al., 2018). See, then, table 2.

The table 2 reveals that the participants got the lowest mean score in the indicator on facing challenges, wherein their tendency is to give up because they believe they will fail. This is a normal reaction to some challenges in life, because for them it is the easy way out. Instead of facing the challenge, they dip into more negative feelings which resulted to a feeling of burn out. With the economic condition in our country, wherein teachers are claiming for increase in salary, perhaps seeking out pleasure could be the least among their priorities. But activities like exercise help us feel better. Being fit also makes you healthier, which helps in managing emotions (Ali \& Rizvi eds., 2007; and Kiel, 2016).

Having emotional intelligence is being able to understand both ourselves and others, and learning how to have control of these emotions to properly choose what to say and do in order to have the desired outcome. Possessing EI (Emotional Intelligence) is a vital skill for a person, because it lets an individual deal with problems and challenges in the best possible way by making choices based on wise thinking, therefore, creating rapport with others (Wilding, 2010; and Gleeson, 2015).

Managing own emotions is a skill that can be developed and which is well worth acquiring. This dimension of emotional intelligence is something that we have control over and can be managed 
Table 3:

Emotional Intelligence Level of Master Teachers on MOE (Managing Others' Emotions)

\begin{tabular}{lcl}
\hline Indicators & Mean & Verbal Interpretations \\
\hline 1. I know when to speak about my personal problems to others. & 4.56 & High \\
2. Other people find it easy to confide in me. & 3.93 & Above Average \\
3. I like to share my emotions with others. & 3.67 & Above Average \\
4. I arrange events others enjoy. & 4.09 & High \\
5. I present myself in a way that makes a good impression on others. & 4.13 & High \\
6. I compliment others when they have done something well. & 4.31 & High \\
7. When another person tells me about an important event in his or her life, & 4.02 & High \\
I almost feel as though I have experienced this event myself. & & \\
8. I help other people feel better when they are down. & 4.29 & High \\
\hline Overall Mean & $\mathbf{4 . 1 3}$ & High Emotional \\
& & Intelligence \\
\hline
\end{tabular}

Table 4:

Emotional Intelligence Level of Master Teachers on UE (Utilization of Emotions)

\begin{tabular}{lcl}
\hline Indicators & Mean & Verbal Interpretations \\
\hline 1. Some of the major events of my life have led me to re-evaluate what is & 4.22 & High \\
important and not important. & & \\
2. When my mood changes, I see new possibilities. & 3.87 & Above Average \\
3. Emotions are one of the things that make my life worth living. & 3.96 & Above Average \\
4. When I am in a positive mood, solving problems is easy for me. & 4.38 & High \\
5. When I am in a positive mood, I am able to come up with new ideas. & 4.38 High \\
6. When I feel a change in emotions, I tend to come up with new ideas. & 4.16 & High \\
\hline Overall Mean & $\mathbf{4 . 1 6}$ & High Emotional \\
& & Intelligence \\
\hline
\end{tabular}

accordingly ( $c f$ Wilding, 2010; Gleeson, 2015; and Kiel, 2016). See, then, table 3.

It was reflected on table 3 that the two indicators that got the lowest mean scores are the desire to share emotions with others and to confide easily with others. Sharing emotions with others and confiding your problems and concerns with others is not easy, because we do not have control over their emotions towards us. Doing these things need trust and security to a person, in which you know the other person can understand them easily. Managing others' emotions is a skill that needs to be developed among Master Teachers, because their personal relationship is one of the most challenging in the performance of their duties and responsibilities (Alston, 2009; and Ainomugisha, 2018).

Having emotional intelligence is about being mindful of own and other people's emotions. It is using emotions and how it can be managed. EI (Emotional Intelligence) has a set of skills that describes how it can effectively manage their and others' emotions (Hasson, 2012; and Patti et al., 2018). See, then, table 4.

The two indicators, as shown in table 4, with the lowest mean scores in utilization of emotions are seeing new possibilities brought about by mood changes, and regarding emotions as one of the things that make life worth living. These two indicators talk about positivity in life. When we are positive in life, we always see possibilities in any circumstance; we regard our emotions as important part of our lives. It's like one of our senses since it provides information, and we have emotional needs as humans. Being in a 
Table 5:

Summary of Emotional Intelligence Level of Master Teachers

\begin{tabular}{lcc}
\hline Emotional Intelligence (EI) & Weighted Mean & Verbal Interpretations \\
\hline Perception of Emotions & 3.84 & Above Average \\
Managing Own Emotions & 4.01 & High \\
Managing Others' Emotions & 4.13 & High \\
Utilization of Emotions & 4.16 & High \\
\hline Overall & $\mathbf{4 . 0 3}$ & High \\
\hline
\end{tabular}

Table 6:

Leadership Traits of Master Teachers on Intelligence (I)

\begin{tabular}{lcccc}
\hline \multicolumn{1}{c}{ Indicators } & \multicolumn{2}{c}{ Self-Rating } & \multicolumn{2}{c}{ Others' Rating } \\
\cline { 2 - 5 } & Mean & Verbal Interpretation & Mean & Verbal Interpretation \\
\hline $\begin{array}{l}\text { 1. Articulate: Communicates } \\
\text { effectively with others. }\end{array}$ & 4.27 & High & 4.24 & High \\
$\begin{array}{l}\text { 2. Perceptive: Is discerning and } \\
\text { insightful. }\end{array}$ & 4.18 & High & 4.13 & High \\
\hline Overall & $\mathbf{4 . 2 2}$ & High & $\mathbf{4 . 1 9}$ & High Leadership Trait \\
\hline
\end{tabular}

positive mood help to come up with new ideas, this indicator got the highest mean score under the dimension of utilization of emotions. It is using our emotions to our advantage. This skill can be very useful to Master Teachers as they engage in different challenges in the performance of their duties and responsibilities. Utilization of emotions is the ability to promote emotional and intellectual growth (Cerado \& Abdullah, 2015; and Poonamallee et al., 2018).

Having EI (Emotional Intelligence) is tantamount to being capable of understanding feelings and using this capability and energy in productive ways. It concerns actions in which people recognize, understand, and apply their power in an effective way (Gardenswartz, Cherbosque \& Rowe, 2008; and Poonamallee et al., 2018). See, then, table 5.

Based on table 5, Master Teachers utilized their emotions in a more positive way, they know how to manage own emotions and others' emotions. However, the data of the study also revealed that their perception of emotions can still be enhanced and developed for them to be emotionally intelligent. Perception of emotions refers to the capacity to be sensitive to the feelings of an individual and those around him/her. This factor of emotional intelligence is described as the ability to understand the non-verbal messages, feelings, and emotions of other people by looking at their facial expressions or listening to the tone of their voice; to be aware of the non-verbal messages sent to others; to be aware of one's emotions; to know why one's emotions change; and to understand why people feel the way that they do (Ciarrochi, Chan \& Bajgar, 2001; and Llego, 2017).

The data of the study revealed that the participants generally have high emotional intelligence. The Master Teachers scored either high or above average in the SSEIT (Schutte Self-Report Emotional Intelligence Test), which runs similar to the findings of the study by C. Birol et al. (2009), citing that a Teacher's level of emotional intelligence at school can be effective in building strong teacherstudent communication, coping with stress and conflict, building a positive school environment, and acquiring academic success (cf Austin et al., 2004; Birol et al., 2009; Schutte, Malouff \& Bhullar, 2009; and 
Table 7:

Leadership Traits of Master Teachers on SC (Self-Confidence)

\begin{tabular}{lcccc}
\hline \multicolumn{1}{c}{ Indicators } & \multicolumn{2}{c}{ Self-Rating } & \multicolumn{2}{c}{ Others' Rating } \\
\cline { 2 - 5 } & Mean & Verbal Interpretation & Mean & Verbal Interpretation \\
\hline $\begin{array}{l}\text { 1. Self-Confident: Believes in him/ } \\
\text { herself and his/her ability. }\end{array}$ & 4.18 & High & 4.27 & High \\
$\begin{array}{l}\text { 2. Self-Assured: Is secure with self, } \\
\text { free of doubts. }\end{array}$ & 4.11 & High & 4.24 & High \\
\hline Overall & $\mathbf{4 . 1 4}$ & High Leadership Trait & $\mathbf{4 . 2 6}$ & High Leadership Trait \\
\hline
\end{tabular}

Table 8:

Leadership Traits of Master Teachers on Determination (D)

\begin{tabular}{lcccc}
\hline \multicolumn{1}{c}{ Indicators } & \multicolumn{2}{c}{ Self-Rating } & \multicolumn{2}{c}{ Others' Rating } \\
\cline { 2 - 5 } & Mean & Verbal Interpretation & Mean & Verbal Interpretation \\
\hline $\begin{array}{l}\text { 1. Persistent: Stays fixed on the goals, } \\
\text { despite interference. }\end{array}$ & 4.11 & High & 4.33 & High \\
$\begin{array}{l}\text { 2: Determined: Takes a firm stand, acts } \\
\text { with certainty. }\end{array}$ & 4.22 & High & 4.33 & High \\
$\begin{array}{l}\text { 3. Conscientious: Is thorough, } \\
\begin{array}{l}\text { organized, and controlled. } \\
\text { 4. Diligent: Is persistent, hardworking. }\end{array}\end{array}$ & 4.13 & High & 4.27 & High \\
\hline Overall & $\mathbf{4 . 1 9}$ & High Leadership Trait & 4.36 & High \\
\hline
\end{tabular}

Rafols, 2015). See, then, table 6.

Table 6 presents the leadership traits of the Master Teachers with the calculated weighted mean for each category. The table shows that Master Teachers are articulate and perceptive. They deserve to be in their position, because of their skills and competencies. Master Teachers continue to strive to increase their expertise and mastery of different subject matters and pedagogical knowledge as well as their efficiency and effectiveness as educators. This explains the result why Master Teachers scored high in the factor of intelligence (Westbrook et al., 2013; and Alegado, 2018). See, then, table 7.

The table 7 shows the leadership traits of Master Teachers on self-confidence. The result indicates that Master Teachers have high leadership traits on self-confidence with an overall mean score of 4.14 (selfrating), which is also related to the result of the others' rating at 4.26. The two indicators which are items 1 and item 2 show that the participants scored high on self-confidence.

The findings revealed that Master
Teachers are self-confident and self-assured, because of their expertise and technical know-how in majority of their tasks. The result is also congruent to the studies of Earvene Jared Cunanan \& Christopher Chua (2015) and Paul John Edrada Alegado (2018), wherein they proved that truly, Master Teachers are capable of doing better work which gives them the confidence in performing their tasks (Cunanan \& Chua, 2015; and Alegado, 2018). See, then, table 8.

Table 8 reflects the leadership traits of Master Teachers on determination. The result indicates that Master Teachers have high leadership traits on determination with an overall mean score of 4.19 (self-rating), which is also related to the result of the others' rating at 4.32 . The four indicators which are items $1,2,3$, and 4 show that the participants scored high on the leadership trait on determination, their position as Master Teachers is a product of hard work and diligence before they were promoted in that position. Master Teachers find challenges in the form of academic tasks, 
Table 9:

Leadership Traits of Master Teachers on Integrity (IG)

\begin{tabular}{lcccc}
\hline \multicolumn{1}{c}{ Indicators } & \multicolumn{2}{c}{ Self-Rating } & \multicolumn{2}{c}{ Others' Rating } \\
\cline { 2 - 5 } & Mean & Verbal Interpretation & Mean & Verbal Interpretation \\
\hline $\begin{array}{l}\text { 1. Trustworthy: Is authentic and } \\
\text { inspires confidence. }\end{array}$ & 4.33 & High & 4.42 & High \\
$\begin{array}{l}\text { 2. Dependable: Is consistent and } \\
\text { reliable. }\end{array}$ & 4.18 & High & 4.29 & High \\
\hline Overall & $\mathbf{4 . 2 6}$ & High Leadership Trait & $\mathbf{4 . 3 6}$ & High Leadership Trait \\
\hline
\end{tabular}

Table 10:

Leadership Traits of Master Teachers on Sociability (S)

\begin{tabular}{lcccc}
\hline \multicolumn{1}{c}{ Indicators } & \multicolumn{2}{c}{ Self-Rating } & & Others' Rating \\
\cline { 2 - 5 } & Mean & Verbal Interpretation & Mean & Verbal Interpretation \\
\hline $\begin{array}{l}\text { 1. Friendly: Shows kindness and } \\
\text { warmth. }\end{array}$ & 4.27 & High & 4.38 & High \\
$\begin{array}{l}\text { 2. Outgoing: Talks freely, gets along } \\
\text { well with others. }\end{array}$ & 4.09 & High & 4.11 & High \\
$\begin{array}{l}\text { 3. Sensitive: Shows tolerance, is } \\
\text { tactful and sympathetic. }\end{array}$ & 4.27 & High & 4.20 & High \\
$\begin{array}{l}\text { 4. Empathic: Understands others, } \\
\text { identifies with others. }\end{array}$ & 4.29 & High & 4.33 & High \\
\hline Overall & $\mathbf{4 . 2 3}$ & High Leadership Trait & $\mathbf{4 . 2 6}$ & High Leadership Trait \\
\hline
\end{tabular}

which they think can improve the learning skills and personal growth of the students. They are determined to accomplish their duties and responsibilities in the school organization ( $c f$ Cunanan \& Chua, 2015; Bush et al., 2016; and Alegado, 2018). See, then, table 9.

The table 9 shows the leadership traits of Master Teachers on integrity. The result indicates that Master Teachers have high leadership traits on integrity with an overall mean score of 4.26 (self-rating), which is also related to the result of the others' rating at 4.36. The two indicators which are item 1 and item 2 show that the participants scored high on integrity. The findings revealed that as Master Teachers, they are trustworthy and dependable, because they have been through a lot of experiences which made them worthy of the trust (Cunanan \& Chua, 2015; Bush et al., 2016; and Alegado, 2018).

As cited by Earvene Jared Cunanan \& Christopher Chua (2015) and Paul John
Edrada Alegado (2018) that Master Teachers undergo evaluation by immediate superior. They are being evaluated in accordance with their performance. Their integrity should always prove that they really deserve the position, because they are meticulously chosen from the best teachers in the field. The result shows that the Master Teachers scored high in the leadership trait on integrity (Cunanan \& Chua, 2015; and Alegado, 2018). See, then, table 10.

The table 10 indicates that Master Teachers scored high on being emphatic, and this trait helps them to understand teachers not on the same position with them and to be able to extend their help with the best of their abilities. This trait will also remind them on where and how they have started as teachers. Other indicators on sociability also scored high which indicates their academic leadership.

As mentioned also by Earvene Jared Cunanan \& Christopher Chua (2015); Tony 
Table 11:

Summary of LT (Leadership Traits) of Master Teachers

\begin{tabular}{lcccc}
\hline \multirow{2}{*}{ Indicators } & \multicolumn{2}{c}{ Self-Rating } & Others' Rating \\
\cline { 2 - 5 } & Mean & Verbal Interpretation & Mean & Verbal Interpretation \\
\hline Intelligence & 4.22 & High & 4.19 & High \\
Self-Confidence & 4.14 & High & 4.26 & High \\
Determination & 4.19 & High & 4.32 & High \\
Integrity & 4.26 & High & 4.36 & High \\
Sociability & 4.23 & High & 4.26 & High \\
\hline Overall & $\mathbf{4 . 2 1}$ & High LT & $\mathbf{4 . 2 8}$ & High LT
\end{tabular}

Table 12:

Correlation of EI (Emotional Intelligence) and LT (Leadership Trait) per Components

\begin{tabular}{|c|c|c|c|c|c|c|c|c|c|c|c|c|}
\hline & \multicolumn{2}{|c|}{ Intelligence } & \multicolumn{2}{|c|}{ Self-Confidence } & \multicolumn{2}{|c|}{ Determination } & \multicolumn{2}{|c|}{ Integrity } & \multicolumn{2}{|c|}{ Sociability } & \multicolumn{2}{|c|}{ Leadership Trait } \\
\hline & $\mathrm{R}$ & p-value & $r$ & p-value & $\mathrm{r}$ & p-value & $\mathrm{r}$ & p-value & $\mathrm{r}$ & $\mathrm{p}$-value & $\mathrm{r}$ & p-value \\
\hline PE & -.0 .005 & & 0.103 & & 15 & & .072 & & 0.052 & & 0.073 & \\
\hline & -0.054 & & -0.039 & & & & 0.023 & & -0.003 & & & 977 \\
\hline MOE & 0.122 & 0.423 & 0.242 & 0.109 & 0.274 & .068 & 0.239 & & 0.178 & 0.242 & 0.235 & .121 \\
\hline UE & & & & & & & & & & & & \\
\hline EI & 0.074 & 0.629 & 0.163 & 0.285 & 0.170 & 0.263 & 0.115 & 0.452 & 0.132 & 0.388 & 0.145 & 0.343 \\
\hline
\end{tabular}

Legend: PE = Perception of Emotions; MOWE = Managing Own Emotions; MOE = Managing Others' Emotions; UE = Utilization of Emotions; and EI = Emotional Intelligence

Bush et al. (2016); and Paul John Edrada Alegado (2018) that one of the relevant and work related tasks of a Master Teacher is to maintain good relationship with teachers and other school personnel, students, and community. And this also explains the result why the Master Teachers scored high in the leadership trait on sociability (Cunanan \& Chua, 2015; Bush et al., 2016; and Alegado, 2018). See, then, table 11.

The scores on the table 11 would say that five indicators of leadership traits are relatively high with a mean score of above 4.00 , both in the self-rating and in others' rating. It shows that the Master Teachers have high leadership trait in all the five major leadership traits. The data of the study revealed that the participants generally have high leadership trait, as can be inferred from their high LTQ (Leadership Trait Questionnaire) scores. The results of the study on leadership traits of Master Teachers corroborate the study of J.S. Gonzalez (2000), and other scholars, that leadership trait is critical for a healthy organization.
Leaders that possess good leadership traits add stability to the people they supervise and the organization as a whole. Likewise, as revealed in the study, Master Teacher participants have high leadership traits, implying that they are an asset of their organization (cf Gonzalez, 2000; Noe, 2012; and Ovans, 2015). See, then, table 12.

As evident in table 12, the five major leadership traits and the dimensions of emotional intelligence are not correlated. Overall, the Pearson Product-Moment Correlation statistics shows that there is no significance or correlation among the variables being tested. This indicates that EI (Emotional Intelligence) is not directly correlated to leadership and that they are not dependent on each other ( $c f$ Noe, 2012; Harney, 2015; and Bush et al., 2016).

The findings revealed that a Master Teacher with high emotional intelligence is not a guarantee of being a leader. In the same manner, a Master Teacher who possesses high leadership traits does not guarantee that he/she is emotionally 
intelligent. It can also be concluded that Master Teachers with high emotional intelligence are not actually leaders, and are perhaps not meant for management position, but are suited for instruction only. In the same way, Master Teachers with high leadership traits are not emotionally intelligent (Noe, 2012; Harney, 2015; Bush et al., 2016; and Dollard, 2018).

The findings of the study are congruent to that of P.D. Berardi (2015), who found out that there was no statistically significant relationship between overall emotional intelligence and authentic leadership (Berardi, 2015). The results indicate that one can exist without the other. There are also no causative or predictive properties between the two variables. EI does not guarantee ethical leadership. It also affirms the study of C.A. Hall (2007) that did a correlation analysis, results of which revealed a negative relationship between total emotional intelligence and total leadership scores; hence, this gives rise to the findings that ability-based emotional intelligence is not part of the criteria necessary for effective leadership ( $c f$ Hall, 2007; Noe, 2012; and Dollard, 2018).

The findings contradict what were reported in the literature and the findings of several studies done to show the correlation between emotional intelligence and leadership. According to D.P. Goleman (1995), leadership is almost all emotional intelligence (Goleman, 1995). K.B. Miller (2015) also proved that emotional intelligence and leadership skills are two prevalent skills linked to successful performance in the workplace and effective leadership (Miller, 2015).

M.E. Burbach (2004) affirmed that emotional intelligence predicts all leadership styles (Burbach, 2004). Emotional intelligence competencies are connected to leadership, there is a positive relationship between them (Cobankiat \& Leehok, 2010; and Batool, 2013). Similar to the findings done here in the Philippines by B. Batool (2013) and L.C. Canlas (2014), this proved that there is a positive relationship between emotional intelligence and effective leadership ( $c f$ Salovey \& Mayer, 1990; Mayer, Roberts \& Barsade, 2008; Batool, 2013; Parrish, 2013; and Canlas, 2014).

\section{CONCLUSION}

This study determined evidence to support that Master Teachers have high emotional intelligence and high leadership trait. This may entail that they have the qualities of leaders, who are really next in line.

Although not significantly related, the present state of emotional intelligence can still serve as a reference to further enhance the leadership trait of the participants. With enhanced leadership trait, Master Teachers can readily face challenges they encounter relevant to their duties and responsibilities.

There is a negative relationship between the variables involved in the study, but emotional intelligence may be a contributory factor for the improvement of leadership trait or vice versa.

The recommendations are the School Administration with the help of the Guidance Office may utilize or develop different approaches, interventions, and techniques that will help Master Teachers understand and recognize their very own emotions. They should emphasize the importance of being emotionally intelligent teachers, so that they can face more complicated challenges in the field of education, especially in their relationship with teachers.

More trainings and seminars can be conducted for Master Teachers to sustain their LT (Leadership Traits). Any leadership training program must incorporate activities or experiences on the different factors of emotional intelligence.

Parallel studies can be conducted using at least 100 participants to determine the 
correlation of two variables that were tested. Parallel studies can also be conducted by future researchers to analyze other possible variables that affect the emotional intelligence or the leadership traits of Master Teachers, such as educational practices, policies, latest trends in education, educational management, and others.

School administrators can also include EI (Emotional Intelligence) and LT (Leadership Trait) as factors for identifying and preparing faculty members for the position of Master Teacher. ${ }^{1}$

\section{References}

Ainomugisha, Gerald. (2018). "The Importance of Emotional Intelligence in Leadership". Available online at: https://inside.6q.io/emotionalintelligence-in-leadership/ [accessed in Manila, the Philippines: January 15, 2019].

Alegado, Paul John Edrada. (2018). “The Challenges of Teacher Leadership in the Philippines as Experienced and Perceived by Teachers" in International Journal of Education and Research, Vol.6, No.6 [June]. Available online also at: http://www.ijern.com/ journal/2018/June-2018/22.pdf [accessed in Manila, the Philippines: January 22, 2019].

Ali, S. \& M. Rizvi [eds]. (2007). Quality in Education: Teaching and Leadership in Challenging Times, Volume 2. Karachi: Aga Khan University, Institute for Educational Development. Available online also at: $\underline{h t t p}: / /$ ecommons.aku.edu/books/7 [accessed in Manila, the Philippines: January 15, 2019].

Alston, Barbara A. (2009). "An Examination of the Relationship between Emotional Intelligence and Leadership Practices". Unpublished Ph.D. Dissertation. USA [United States of America]: School of Business and Entrepreneurship, Nova Southeastern University. Available online also at: http://citeseerx.ist.psu.edu/ viewdoc/download?doi=10.1.1.540.3466\&rep

\footnotetext{
${ }^{1}$ Statement: We, hereby, declare that a scientific article that we wrote, it has never been submitted for publication in any other journals. In this article, there is no work or opinions that have been written or published in another person, except in writing clearly listed as the sources listed in the Bibliography or References. So, this article is really not product of plagiarism.
}

$=$ rep1\&type $=$ pdf $[$ accessed in Manila, the Philippines: January 15, 2019].

Anand, R. \& S.G. Udaya. (2010). "Emotional Intelligence and its Relationship with Leadership Practices" in International Journal of Business and Management, Vol.5, No.2.

Ang, E.K., P.M. Carlos \& J. Umali. (2014). “A Multi-Dimensional Study on the Relationship of Emotional Intelligence to the Multitasking Ability of Nursing Students: A Structural Equation Modeling Approach". Unpublished Master's Thesis. The Philippines: De La Salle University.

Austin, E. et al. (2004). "Measurement of Trait EI: Testing and Cross-Validating a Modified Version of Schutte et al.'s (1998) Measure" in Personality and Individual Differences, Volume 36, pp.555-562.

Bar-on, R. (1997). The Emotional Quotient Inventory (EQ-i): A Test of Emotional Intelligence. Toronto, Canada: Multi-Health Systems, Inc.

Batool, B. (2013). "Emotional Intelligence and Effective Leadership" in Journal of Business Studies, Vol.4, No.3 [Quarterly].

Bennis, W. (2009). On Becoming a Leader. New York: Basic Books.

Berardi, P.D. (2015). "The Relationship between Emotional Intelligence and Authentic Leadership in Naval Special Warfare Leadership".

Unpublished Ph.D. Dissertation. The Philippines: Capella University.

Birol, C. et al. (2009). "Analysis of the Emotional Intelligence Level of Teachers" in PROCEDIA: Social and Behavioral Sciences, Volume 1(1), pp.2606-2614.

Boateng, Isaac. (2014). "A Quantitative Case Study of Transformational Leadership Characteristics of Valley View University in Ghana" in Dissertations, No.234. Available online also at: https://digitalcommons.andrews. edu/dissertations/234 [accessed in Manila, the Philippines: January 8, 2019].

Brown, Carlton. (2014). "The Effects of Emotional Intelligence (EI) and Leadership Style on Sales Performance" in Economic Insights: Trends and Challenges, Vol.III(LXVI), No.3, pp.1-14. Available online also at: http://www.upg-bulletinse.ro/archive/2014-3/1. Brown.pdf [accessed in Manila, the Philippines: January 15, 2019].

Burbach, M.E. (2004). "Testing the Relationship between Emotional Intelligence and Full-Range Leadership as Moderated by Cognitive Style and Self-Concept". Unpublished Ph.D. Dissertation. USA [United States of America]: The Graduate College of the University of Nebraska.

Bush, Tony et al. (2016). "Master Teachers as Teacher Leaders: Evidence from Malaysia and the Philippines" in ISEA Journal, Vol.43, 
No.2, pp.19-40. Available online also at: $\underline{\text { http:// }}$ eprints.nottingham.ac.uk/39454/1/ISEA $\% 20$ MASTER \%20TEACHER \%20PAPER $\% 20$ PROOFS\%202016.pdf [accessed in Manila, the Philippines: January 22, 2019].

Canlas, L.C. (2014). "The Relationship between Emotional Intelligence and Leadership Potential of Faculty Members in Selected Private Basic Education School". Unpublished Master's Thesis. Manila, the Philippines: Ateneo de Manila University.

Cerado, Ernie C. \& Samsudin N. Abdullah. (2015). "Emotional Intelligence and Social Competence: Antecedents of School Administrators' Transformational Leadership Qualities" in Journal of US-China Public Administration, Vol.12, No.3 [March], pp.180-184. Available online also at: http://www.davidpublisher.com/Public/uploads/ Contribute/558a1d986fa68.pdf [accessed in Manila, the Philippines: January 22, 2019].

Cherniss, C. (2006). "Emotional Intelligence: What Does the Research Really Indicate?" in Educational Psychologist, Volume 41(4), pp.239245. Available online also at: http://dx.doi. org/10.1207/s15326985ep4104 4 [accessed in Manila, the Philippines: January 8, 2019].

Chishti, S. et al. (2011). "Impact of Emotional Intelligence on Team Performance in Higher Education Institutes" in International Online Journal of Educational Sciences, Volume 3(1), pp.30-46.

Ciarrochi, J., A.Y.C. Chan \& J. Bajgar. (2001). "Measuring Emotional Intelligence in Adolescents" in Personality and Individual Difference, Volume 31, pp.1105-1119.

Clark, W.R., M. Golder \& S.N. Golder. (2010). "Power and Politics: Insights from an Exit, Voice, and Loyalty Game". Available online at: https:// projects.iq.harvard.edu/files/pegroup/files/clark golder.pdf [ccessed in Manila, the Philippines: January 15, 2019].

Cobankiat, P.O. \& P.J.T. Leehok. (2010). "Correlation of Emotional Intelligence and Leadership among Student-Leaders: Goleman's Four Competencies". Unpublished Master's Thesis. The Philippines: De La Salle University.

Cunanan, Earvene Jared \& Christopher Chua. (2015). "How Teachers View the Need to Develop Self-Mastery Skills among Teacher Education Students?" in Asia Pacific Journal of Multidisciplinary Research, Vol.3, No.4, pp.105-111. Available online also at: https://www. academia.edu/28667589/How teachers view the need to develop self- mastery skills among teacher education students [accessed in Manila, the Philippines: January 22, 2019].
Daloos, Monica Joy O. (2015). “Emotional Intelligence and Adversity Quotient of Selected Helping Professionals". Unpublished Master Thesis. Manila: Department of Psychology, Institute of Arts and Sciences, Far Eastern University. Available online also at: https://www. peaklearning.com/documents/PEAK GRI daloos.pdf [accessed in Manila, the Philippines: January 8, 2019].

Dollard, Christopher. (2018). "Emotional Intelligence is Key to Successful Leadership" in The Gottman Institute: A Research-Based Approach to Relationship, on July 19. Available online also at: https://www.gottman.com/blog/emotionalintelligence-key-successful-leadership/ [accessed in Manila, the Philippines: January 8, 2019].

Dolev, N. \& S. Leshem. (2017). "Developing Emotional Intelligence Competence among Teachers" in Teacher Development, Volume 21(1), pp.21-39. Available online also at: https://doi.or $\mathrm{g} / 10.1080 / 13664530.2016 .1207093$ [accessed in Manila, the Philippines: January 8, 2019].

Drigas, A.S. \& C. Papoutsi. (2018). “A New Layered Model on Emotional Intelligence" in Behavioral Sciences, Volume 8(5). Available online also at: https://www.ncbi.nlm.nih.gov/pmc/ articles/PMC5981239/ [accessed in Manila, the Philippines: January 8, 2019].

Dumitru, A., A.G. Motoi \& A.B. Budica. (2015). "What Kind of Leader is a Manager?" in Annals of the University of Craiova for Journalism, Communication, and Management, Volume 1, pp.50-60. Available online also at: http://www. aucjc.ro/wp-content/uploads/2015/12/aucjcmvol-1-2015-50-60.pdf [accessed in Manila, the Philippines: January 8, 2019].

Gardenswartz, L., J. Cherbosque \& R. Rowe. (2008). Emotional Intelligence for Managing Results in a Diverse World: The Hard Truth about Soft Skills in the Workplace. Mountain View, California: Davies Black Publication.

Gleeson, Brent. (2015). "5 Aspects of Emotional Intelligence Required for Effective Leadership". Available online at: https://www.inc.com/brentgleeson/5-aspects-of-emotional-intelligencerequired-for-effective-leadership.html [accessed in Manila, the Philippines: January 8, 2019].

Goleman, D.P. (1995). Emotional Intelligence: Why it Can Matter More than IQfor Character, Health, and Lifelong Achievement. New York: Bantam Books.

Golis, C. (2007). "Emotional Intelligence: A Brief History of EQ-Practical EQ-Chris Golis Emotional Intelligence Courses \& Books". Available online at: $\underline{w w}$. emotionalintelligencecourse.com [accessed in 
Manila, the Philippines: December 7, 2018].

Gonzalez, J.S. (2000). "Tangled Up in Blue: Unraveling the Links between Emotional Distress and Treatment". Available online at: www.care. diabetesjournals.org [accessed in Manila, the Philippines: December 7, 2018].

Hall, C.A. (2007). "Examining the Relationship between Leadership Effectiveness, Emotional Intelligence, and Coping Mechanisms for Stress of School Administrators". Unpublished Ph.D. Dissertation. USA [United States of America]: University of Massachusetts Lowell.

Harney, Ellen I. (2015). "Correlation of Emotional Intelligence of School Leaders and School Climate: A Cross-Cultural Comparison Between American and South Korean Schools" in Theses and Dissertations, No.196. Available online also at: http://knowledge.library.iup.edu/etd/196 [accessed in Manila, the Philippines: January 22, 2019].

Hasson, G. (2012). Brilliant Emotional Intelligence: Harness the Power of Emotions, Succeed in All Areas of Your Life. Harlow: Pearson Life.

Hertwig, R.W. (2016). "Examining the Relationship of Trait Emotional Intelligence and Leadership Style for Professional Engineers". Unpublished Ph.D. Dissertation. The Philippines: Capella University.

Ishmaill, I. et al. (2012). "The Role of Emotional Intelligence on Job Performance" in International Journal of Business and Social Science, Vol.3, No.1.

Kannaiah, D. \& R. Shanthi. (2015). “A Study on Emotional Intelligence at Work Place" in European Journal of Business and Management, Vol.7, No.24. Available online also at: https://researchonline.jcu. edu.au/40340/1/40340\%20Kannaiah $\% 20$ and $\% 20$ Shanthi\%202015.pdf [accessed in Manila, the Philippines: January 15, 2019].

Kiel, Dana. (2016). "The Economics of Emotional Intelligence: Defining a Hierarchy of Soft Skills". Available online at: https://www.academia. edu/25638703/The Economics of Emotional Intelligence_Defining_a_Hierarchy_of_Soft Skills [accessed in Manila, the Philippines: January 15, 2019].

Kolzow, David R. (2014). "Leading from Within: Building Organizational Leadership Capacity". Available online at: https://www.iedconline.org/ clientuploads/Downloads/edrp/Leading_from Within.pdf [accessed in Manila, the Philippines: January 15, 2019].

Kreitz, Patricia A. (2009). "Leadership and Emotional Intelligence: A Study of University Library Directors and Their Senior Management Teams" in C\&RL: College \& Research Library, Vol.70, No.6. Available online also at: https://crl.acrl.org/index. $\mathrm{php} / \mathrm{crl} /$ article/view/16043 [accessed in Manila, the
Philippines: January 8, 2019].

Kumar, Sanjay. (2014). "Establishing Linkages between Emotional Intelligence and Transformational Leadership" in Industrial Psychiatry Journal, Volume 23(1), January-June, pp.1-3. Available online also at: https:/www.ncbi. nlm.nih.gov/pmc/articles/PMC4261205/ [accessed in Manila, the Philippines: January 8, 2019].

Leigh, C. (2012). "Examining the Relationship Between Emotional Intelligence and Leadership Styles of U.S. Navy Senior Enlisted Leader". Unpublished Ph.D. Dissertation. USA [United States of America]: North Central University.

Liguo, X. et al. (2014). "Adding Dynamics to a Static Theory: How Leader Traits Evolve and How They are Expressed". Available online at: www. elsevier.com/locate/leagua [accessed in Manila, the Philippines: December 7, 2018].

Llego, Jordan Hiso. (2017). "Demographic Influence on Emotional Intelligence of Science Technology and Engineering Teachers in Region 1 Philippines" in IJIR: Imperial Journal of Interdisciplinary Research, Volume 3, Issue 3. Available online also at: https://files.eric.ed.gov/ fulltext/ED573332.pdf [accessed in Manila, the Philippines: January 22, 2019].

Lopes, P.N. (2016). "Emotional Intelligence in Organizations: Bridging Research and Practice". Available online at: www.journals. sagepub.com $>$ doi $>$ abs [accessed in Manila, the Philippines: December 7, 2018].

Lough, L. (2016). "Emotional Intelligence Training Intervention: A Mixed Method Study of Air Force Staff Sergeants". Unpublished Ph.D. Dissertation. The Philippines: University of Phoenix.

Mayer, John D. \& Peter Salovey. (1997). "Emotional Development and Emotional Intelligence: Educational Implications". Available online at: https://.ei.yale.edu/...?emotional-developmentand-emotional-intelligence-implication [accessed in Manila, the Philippines: December 7, 2018].

Mayer, John D., Peter Salovey \& David R. Caruso. (2008). "Emotional Intelligence: New Ability or Eclectic Traits?" in American Psychologist, Vol.63, No.6, pp.503-517. Available online also at: https://www.psychologytoday.com/ sites/default/files/attachments/1575/rp2008mayersaloveycarusob.pdf [accessed in Manila, the Philippines: January 15, 2019].

Mayer, J.D., R. Roberts \& S. Barsade. (2008). "Human Abilities: Emotional Intelligence" in Annual Review of Psychology, Volume 59, pp.507-536. Available online also at: https://doi. org/10.1146/annurev.psych.59.103006.093646 [accessed in Manila, the Philippines: December 7, 2018]. 
Mayer, J.D., D. Caruso \& P. Salovey. (2016). "Measuring Emotional Intelligence: Responses to Schlegel and to Legree, Mullins, and Psotka". Available online at: www.journals.sagepub.com/ doi/full/10.11771754073916650505 [accessed in Manila, the Philippines: December 7, 2018].

McCanon, C. \& M. Jeanine. (2015). "The Relationship between Emotional Intelligence and Servant Leadership among Public School Principals and Assistant Principals". Unpublished Ph.D. Dissertation. The Philippines: Capella University.

McCauley, C.D. \& M.W. McCall. (2014). Using Experience to Develop Leadership Talent: How Organization Leverage on the Job Development. San Francisco, CA: Jossey-Bass.

Mihelic, K.K., B. Lipicnik \& M. Tekavcic. (2010). "Ethical Leadership" in International Journal of Management \& Information Systems, Vol.14, No.5 [Fourth Quarter]. Available online also at: http://www.ef.uni-lj.si/docs/osebnestrani/MIhelic Lipicnik Tekavcic 2010 clute.pdf [accessed in Manila, the Philippines: January 8, 2019].

Miller, K.B. (2015). “The Relationship between Emotional Intelligence Behaviors and Leadership Practices among Women Leaders in Education and Business Organizations". Unpublished Ph.D. Dissertation. The Philippines: Capella University.

Murphy, Kevin T. (2006). "The Relationship between Emotional Intelligence and Satisfaction with Life After Controlling for Self-Esteem, Depression, and Locus of Control among Community College Students" in Graduate Theses and Dissertations. Available online also at: http://scholarcommons. usf.edu/etd/2640 [accessed in Manila, the Philippines: January 8, 2019].

Narong, David Kongpiwatana. (2015). "The Relationship between Leaders' Emotional Intelligent and Their Perceived Leadership Effectiveness". Unpublished Ph.D. Thesis. Massachusetts: College of Professional Studies, Northeastern University of Boston. Available online also at: https://repository. library.northeastern.edu/files/neu:cj82mx46w/ fulltext.pdf [accessed in Manila, the Philippines: January 15, 2019].

Noe, Jeff. (2012). "The Relationship between Principal's Emotional Intelligence Quotient, School Culture, and Student Achievement”. Unpublished Ph.D. Dissertation. The Philippines: Liberty University. Available online also at: http://citeseerx.ist.psu.edu/viewdoc/ download?doi=10.1.1.473.3221\&rep=rep1\&type $=$ pdf [accessed in Manila, the Philippines: January 22, 2019].

Northouse, P.G. (2013). Leadership: Theory and Practice. Los Angeles: Sage Publications.
Available online at: https://sites.psu.edu [accessed in Manila, the Philippines: December 7, 2018].

Northouse, P.G. (2015). Leadership: Theory and Practice. Los Angeles: Sage Publication, Inc., $7^{\text {th }}$ edition.

Olila, Rowel G. (2012). “Adversity Quotient and Personal Characteristics as Correlates of the Personality-Temperament Traits of Educators in Selected Public and Private Educational Institutions". Unpublished Ph.D. Dissertation. Manila: The Faculty of the School of Graduate Studies, Manuel L. Quezon University. Available online also at: https://www.peaklearning.com/ documents/PEAK GRI olila.pdf [accessed in Manila, the Philippines: January 15, 2019].

Ovans, Andrea. (2015). "How Emotional Intelligence Became a Key Leadership Skill” in $H B R$ : Harvard Business Review, on April 28. Available online also at: https://hbr.org/2015/04/howemotional-intelligence-became-a-key-leadershipskill [accessed in Manila, the Philippines: January 22, 2019].

Parrish, Dominique Rene. (2013). "The Relevance of Emotional Intelligence for Leadership in a Higher Education Context". Available online at: http://dx.doi.org/10.1080/03075079.2013.84222 5 [accessed in Manila, the Philippines: December 7, 2018].

Patti, Janet et al. (2018). "Leading with Emotional Intelligence" in EL: Educational Leadership, Volume 75, on June. Available online also at: http://www.ascd.org/publications/educationalleadership/summer18/vol75/num09/LeadingWith-Emotional-Intelligence.aspx [accessed in Manila, the Philippines: January 8, 2019].

Petrides, K.V. (2017). "Intelligence, Emotional" in Reference Module in Neuroscience and Biobehavioral Psychology, pp.1-6. Available online at: http://www.psychometriclab.com/ adminsdata/files/Emotional $\% 20$ intelligence $\% 20$ - $\% 20$ Elsevier $\% 20 \mathrm{NBP} \% 20$ encyclopedia $\% 20$ (2017).pdf [accessed in Manila, the Philippines: January 8, 2019].

Poonamallee, Latha et al. (2018). "Improving Emotional Intelligence through Personality Development: The Effect of the Smart Phone Application Based Dharma Life Program on Emotional Intelligence" in Frontiers in Psychology, Volume 9. Available online also at: https://www.ncbi.nlm.nih.gov/pmc/articles/ PMC5829461/ [accessed in Manila, the Philippines: January 8, 2019].

Rafols, Jaruvic Clavano. (2015). "Profile, Adversity Quotient ${ }^{\circledR}$, and Multifactor Leadership Characteristics of Student Affairs and Services Administrators: Towards a Leadership 
Management Training Design". Unpublished Ph.D. Dissertation. The Philippines: Graduate Programs, College of Education, Silliman University. Available online also at: https://www. peaklearning.com/documents/PEAK GRI Rafols.pdf [accessed in Manila, the Philippines: January 15, 2019].

Ragasa, R.A.T. (2013). "The Relationship between Emotional Intelligence and Teaching Performance among Nurse Educators". Unpublished Master's Thesis. The Philippines: UST Graduate School.

Reissland, N. (2012). The Development of Emotional Intelligence: A Case Study. London and New York: Routledge.

Roberts, F. (2012). "Trait Approach Leadership". Available online at: https://sites.google. com. $>$ home $>$ trait-ap [accessed in Manila, the Philippines: December 7, 2018 ].

Sabado, Norberta Pahamutang. (2014). "The Influence of Leadership Behavior of School Heads to the Performance of Public and Private High School Teachers in Kidapawan City Division". Unpublished Ph.D. Dissertation. The Philippines: Graduate School, University of Southern Mindanao. Available online also at: https://www.academia.edu/8219636/ The Influence of Leadership_Behavior to the Teachers Performance [accessed in Manila, the Philippines: January 15, 2019].

Salovey, P. \& J.D. Mayer. (1990). "Emotional Intelligence" in Imagination, Cognition, and Personality, Volume 9, pp.185-211. Available online also at: www.ei.yale.edu/publication/ emotional-intelligence $/ 5$ [accessed in Manila, the Philippines: December 7, 2018].

Sathitsemakul, Chanthawan. (2017). "The Influence of Thai Emotional Intelligence on Employees' Knowledge Sharing Attitude in a Commercial Bank in Thailand". Unpublished Ph.D. Dissertation. Bangkok, Thailand: The IKISEA [Institute for Knowledge and Innovation South East Asia], Business School of Bangkok University. Available online also at: http:// dspace.bu.ac.th/bitstream/123456789/2710/1/ Chanthawan_Yo.pdf [accessed in Manila, the Philippines: January 8, 2019].

Schutte, N.S., J.M. Malouff \& M. Bhullar. (2009). "The Assessing Emotions Scale" in C. Stough, D. Saklofske \& J. Parker [eds]. The Assessment of Emotional Intelligence. New York: Springer Publishing, pp.119-135.
Silzer, R. \& A.H. Church. (2009). "The Pearls and Perils of Identifying Potential" in Industrial and Organizational Psychology, Volume 2.

Singh, D. (2015). Emotional Intelligence at Work: A Professional Guide. New Delhi and Thousand Oaks, California: Response Books.

Toniono, R.J. (2015). "The Relationship between Emotional Intelligence and Leadership Style among Community College Leaders". Unpublished Ph.D. Dissertation. The Philippines: Aurora University.

Walters, Stephan Lorentz. (2018). "Emotional Intelligence and Leader Development: Measuring Trait Emotional Intelligence Scores of MidCareer Commissioned U.S. Army Officers" in Dissertations Paper, No.148. Available online also at: $\underline{\text { htps:// }}$ digitalcommons.wku.edu/diss/148 [accessed in Manila, the Philippines: January 15, 2019].

Westbrook, J. et al. (2013). Pedagogy, Curriculum, Teaching Practices, and Teacher Education in Developing Countries. UK [United Kingdom]: University of Sussex. Available online also at: https://eppi.ioe.ac.uk/cms/Portals/0/PDF\%20 reviews $\% 20$ and $\% 20$ summaries/Pedagogy $\% 20$ 2013\%20Westbrook [accessed in Manila, the Philippines: January 22, 2019].

Wilding, C. (2010). Change Your Life with Emotional Intelligence. Oxon: Teach Yourself.

Wouters, Claire, Phil Brull \& Esther LopezZafra. (2018). "Emotional Intelligence, Vigor, and Authentic Leadership: Their Underlying Relationship and Combined Influence on Life Satisfaction, Academic Performance, and Mental Health". Available online at: http:// proceedings.ui.ac.id/index.php/uipssh/article/ viewFile/71/115 [accessed in Manila, the Philippines: January 15, 2019].

Zeichner, Ken. (2008). "A Critical Analysis of Reflection as a Goal for Teacher Education" in Educacao \& Sociedade, Vo.29, No.103, Camipans [May-August]. Available online also at: http://www.scielo.br/scielo.php?script=sci arttext\&pid $=$ S0101-73302008000200012\&lng $=$ en\&nrm=iso\&tlng=en [accessed in Manila, the Philippines: January 15, 2019].

Zoller, K. \& K. Pieston. (2014). Enhancing Your Executive Edge: How to Develop the Skills to Lead and Succeed. New York: McGraw-Hill Educ. 


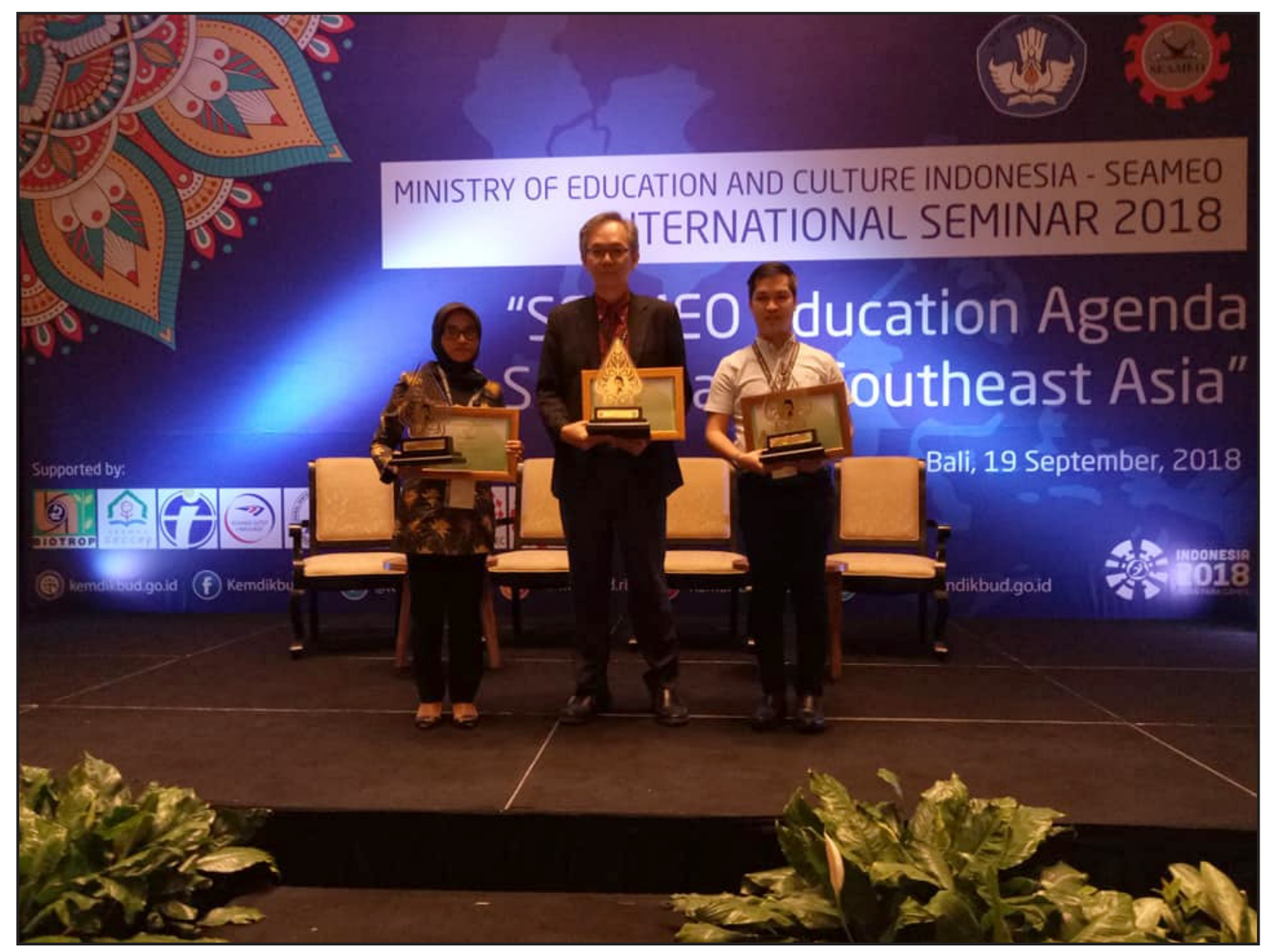

One of the Master Teachers of the Philippines' Senior High School

(Source: http://www.deped.gov.ph, 29/1/2019)

Using a descriptive-correlational research method involving 45 respondents from the 10 Senior High Schools in Pasig City with Master Teachers, the study identified their emotional intelligence and leadership trait, and determined the significant correlations between the two as perceived by the participants. The results show that the respondents were highly emotionally intelligent in managing own emotions, managing others' emotions, and utilization of emotions, but they got above average emotional intelligence in the perception of emotions. On the other hand, the measure of leadership trait showed that they had high leadership trait in all the five major leadership traits. 